\title{
Open Heart Surgery Experience of a High Volume Center During Pandemic
}

\author{
Pandemi Döneminde Yüksek Hacimli Bir Merkezin Açık \\ Kalp Cerrahisi Deneyimi
}

\section{Özgün Araştırma Research Article}

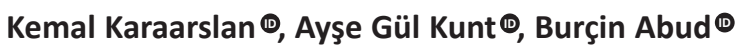

Received/Geliș: 12.08.2021 Accepted/Kabul: 17.08.2021 First Online: 28.09 .2021

Kemal Karaarslan Cardiovasculer Surgery, Tepecik Education and Research Hospital, Health Science Universty, Izmir, Turkey karaaslan4@hotmail.com ORCID: 0000-0002-7279-1281

A. Gül Kunt 0000-0002-1419-8551 B. Abud 0000-0002-2965-6738 Cardiovasculer Surgery, Tepecik Education and Research Hospital, Health Science Universty, izmir, Turkey

Cite as: Karaarslan K, Gül Kunt A, Abud B. Open heart surgery experience of a high volume center during pandemic. Tepecik Ë̆it. ve Araşt. center during pandemic. Tepecik
Hast. Dergisi. 2021;31(3):385-91.

\section{ABSTRACT}

Objective: The aim of the study is to report the results of open heart surgery performed during the pandemic. Methods: One hundred eighty-five symptomatic patients were operated under a median sternotomy with a cardiopulmonary bypass in our pandemic hospital. They were all outpatient and were COVID-negative and strict precautions were taken.

Results: 185 patients were referred to cardiovascular surgery for several type of cardiac operation. All patients were symptomatic due to primary cardiac disease. In-hospital mortality rate was seven times higher in those with Covid-19 (22.2\%) while the non Covid-19 patients had a rate of $(3.4 \%)(p<0.0001)$.

Conclusion: Cardiac surgery is inevitable in symptomatic patients and can be done even with the risk of transmission and death. The patient, cardiac surgeon, and healthcare team should be aware of the ongoing contamination time.

Keywords: Open heart surgery, emergency, COVID-19

öz

Amaç: Çalışmanın amacı pandemi döneminde yapılan açık kalp cerrahisi sonuçlarını bildirmektir.

Yöntem: Yüz seksen beş semptomatik hasta, yüksek hacimli bir pandemi hastanesinde kardiyopulmoner baypas ile median sternotomi altında opere edildi. Hepsi ayakta tedavi gördü ve COVID negatifti. Sıkı önlemler alındı.

Bulgular: 185 hasta herhangi bir kalp ameliyatı da dahil olmak üzere kardiyovasküler cerrahiye yönlendirildi. Tüm hastalar primer hastalığa bağlı olarak semptomatikti. Hastane içi ölüm oranı Covid-19 olanlarda (\%22,2) ve olmayanlarda $(\% 3,4)$ yedi kat daha yüksekti $(p<0,0001)$.

Sonuç: Semptomatik hastalarda kalp cerrahisi kaçınılmazdır ve ölüm riskine karşı bulaşma riski seçilerek yapılabilir. Hasta, kalp cerrahı ve sağıık ekibi devam eden kontaminasyon süresinin farkında olmalıdır.

Anahtar kelimeler: Açık kalp cerrahisi, acil, Covid-19

(C) Telif hakkı TC. Sağık Bakanlı̆ı jzmir Tepecik Eğit. ve Arast. Hastanesi. Logos Tip Yayınclık tarafindan yayınlanmaktadır. Bu dergide yayınlanan bütün makaleler Creative Commons Atf-GayriTicari 4.0 Uluslararası Lisansı ile lisanslanmıştır.

(c) Copyright Association of Publication of the T.C. Ministry of Health Izmir Tepecik Education and Research Hospital.

This journal published by Logos Medical Publishing.

Licenced by Creative Commons Attribution-NonCommercial 4.0 International (CC BY) 


\section{INTRODUCTION}

The world became aware of the Covid-19 outbreak for the first time when China reported to the World Health Organization (WHO) that on December 31, 2019 (1). This mysterious respiratory disease originating from the city of Hubhan, Wuhan, was unknown (2). The epidemic, which was initially perceived as regional affected China and surroundings. Then, the virus begun to cross the Asian borders in the following days and threaten public health globally. The epicenter of the outbreak was first in Europe, and then the United States ranked first in the world in the number of cases ${ }^{(3)}$. On 30 January 2020, the World Health Organisation (WHO) declared the outbreak of Covid-19 (SARS-CoV2) a Public Health Emergency of International Concern. Coronavirus disease 2019 (COVID-19) has been characterized as a pandemic by the WHO on March $11^{\text {th }}, 2020$. The first case was also announced on the same day in Turkey. We operated one hundred eighty-five symtomatic patients during contagious period. We aimed to report our results and discuss the safety of open cardiac surgery.

\section{MATERIAL and METHOD}

After announcement of first case with COVID-19, patients who do not need urgent / emergent therapy were discharged from all hospitals. Large volume hospitals in each city were determined as pandemic hospitals. Elective surgical procedures and nonobligatory treatments were delayed. Flexible working hours have been implemented for all specialist physicians. Totally thirteen cardiovascular surgeons were active in their duty. Two cardiovascular surgery teams with 7 and 6 surgeons were scheculed for 24 hours work.-

This study was performed in a high-volume first line pandemic hospital and approved by the Clinical Research Ethical Committee of XXX Training and Research Hospital between March 2020 and March 2021. 185 patients were included in the study. All patients were discussed between cardiovascular surgery and cardiology departments to decide whether surgery or percutaneous intervention should be performed. Preoperative risk evaluation was determined with European System for Cardiac Operative Risk Evaluation II (total score calculation= old EuroSCORE scoring+EuroSCORE II risk factors). Indications were mostly coronary artery disease while the others were aortic and mitral valve disease, thoracic aortic disease. Patients diagnosed with congenital heart disease and COVID-19 infection were excluded.

All patients were prepared preoperatively in outpatient clinics. Suspected contact history were screened for COVID-19, respiratory samples were obtained from both nasopharyngeal swab and sputum samples and reverse transcription polymerase chain reaction test (RT-PCR) was performed. As the test result can be obtained for up to 12 hours, the patients were followed by strict droplet and contact precautions in a single room. If the test result is negative, chest tomography was performed to exclude the infection in suspicious condition.

The number of health-workers present in the operating room during intubation and operation were minimized (Figure 1). PPE and appropriate for aerosol-generating procedures were utilized.

Cardiovascular intensive care ( $\mathrm{CICU})$ and clinical service were designated as the last place to be hospitalized after other beds were filled with COVID19 patients. The $\mathrm{CICU}$ has a capacity of 6 beds with an isolation bed which was reserved for potentially infected patient (Figure 2). Emergent cardiac operations were also monitored in $\mathrm{CICU}$. Extubation was provided as early as possible in the intensive care. Transferring to the cardiovascular surgery service was routine and monitoring was performed in an isolation room. Only one patient relative was permitted for the patient mobilization and nonmedical needs. This isolated person had no symptom for COVID-19. The relative was always the same person and had appropriate protective equipment (PPE) according to the guidelines recommended by 


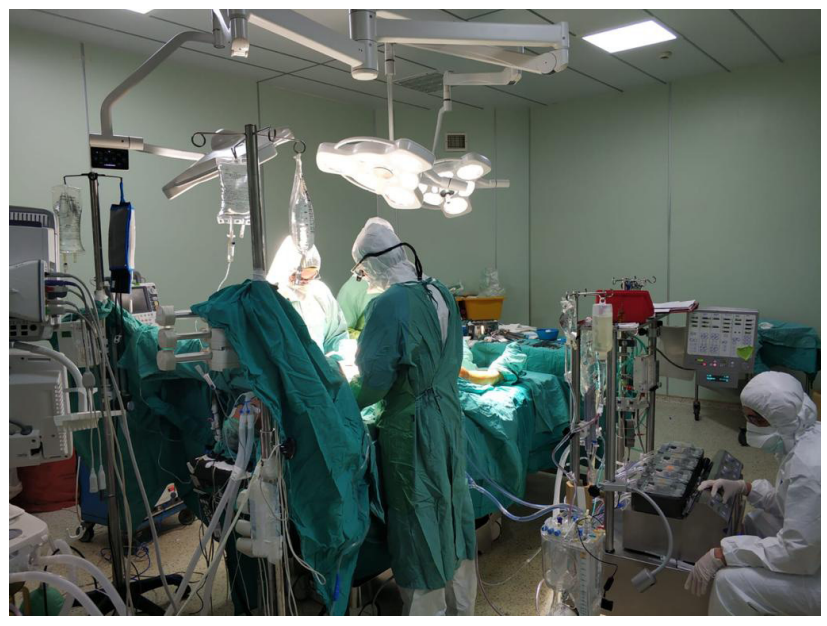

Figure 1. Operating room.

WHO (4). Patient visits by other relatives were restricted strictly by the hospital administration.

After the discharge, the patients were examined, and blood tests were taken in an outpatient clinic. All non-mandatory follow-ups were conducted via telephone calls. Online in-house training programs for the correct use of personal protecting equipment (PPE) and the importance of social distancing was organized by the Ministery of Health.

\section{RESULTS}

When we compare those with Covid-19 $(n=9)$ and those without ( $n=176)$, those with Covid-19 were male $(89.9 \%$ vs $74.2 \%, p=0.004)$ and were found to be more diabetic $(44.4 \% \vee 25.6 \%, p=0.023)$. The calculated EuroSCORE II was (3.91 [1.6ñ6.6] v 2.16 [1.5ñ4.7], $p<0.014$ ) (Table 1). Covid-19 patients had an emergency $(66.6 \%$ vs $50.5 \%, p<0.001)$ and more complex surgical procedures (eg valve and CABG surgery $22.2 \%$ vs $8.5 \%$ ). In addition, in the covidpositive group, longer cardiopulmonary bypass (114 [87-151] v 100 [74-135], $p=0.02$ ) and aortic X-clamp times (82 [61-115] v 69 [50-97], $p=0.022$ ) were detected. No difference was found in terms of intensive care length of stay, EF values, ventilation times and postoperative morbidity in the hospital. Those who were diagnosed with covid stayed an

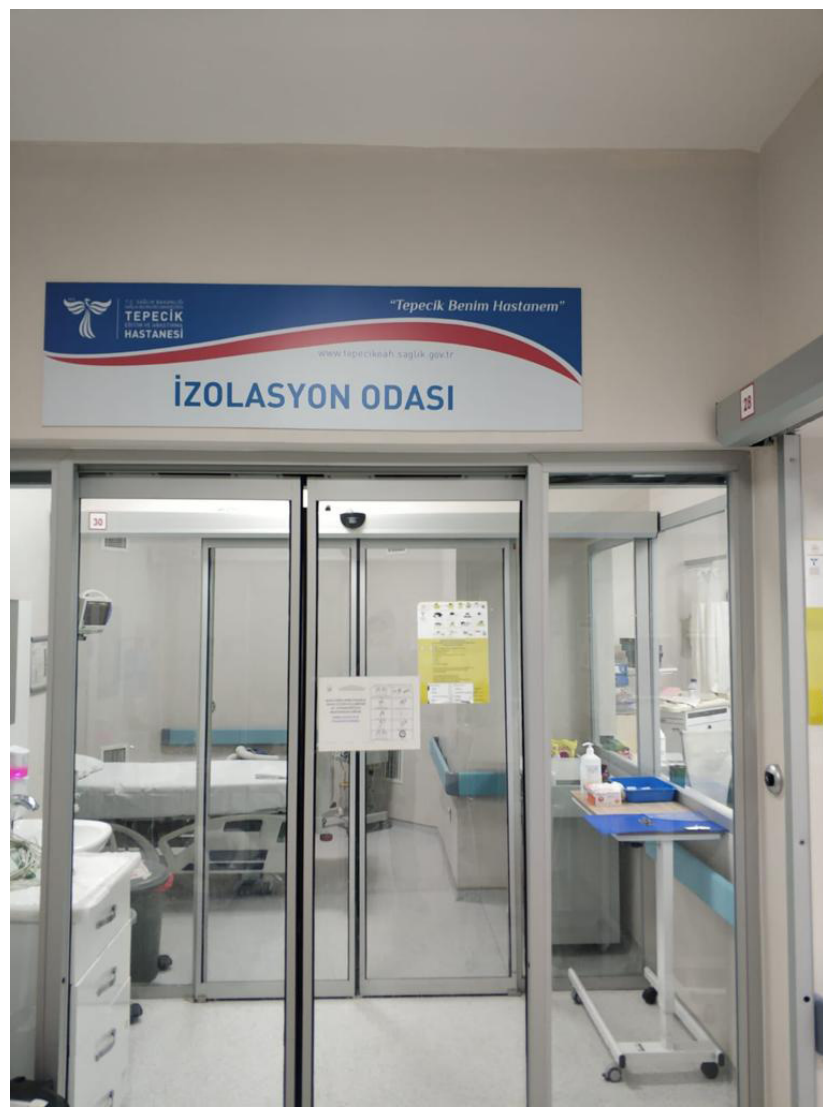

Figure 2. Izolation room

average of 6 days longer in the hospital than those who did not. (13 [7ñ16] v 7 [6ñ9], $p=0.001)$. In addition, in-hospital mortality rate was seven times higher in those with Covid-19 (22.2\%) and those without $(3.4 \%)(p<0.0001)$.

185 patients were referred to cardiovascular surgery for cardiac operation. All patients were symptomatic due to primary disease. All had symptom-free or diagnosed negative by swab test for COVID-19 underwent cardiac surgery between March 2020 to March 2021. They had nasopharyngeal swab and sputum sample. Test-negative but symtomatic (fever and cough) patients were further imagined with chest tomography. In the postoperative follow-up, 9 of the patients were diagnosed with COVID-19 during the hospital stay. There was no significant difference between the preoperative demographic data of the patients except male gender. There was also a statistically significant difference in the covidpositive group in terms of previous cardiac surgery 
Table 1. Preoperative demografic and perop-postop variables.

\begin{tabular}{|c|c|c|c|c|}
\hline Variable & $\begin{array}{c}\text { All patients } \\
(\mathrm{n}=185) \\
\text { mean/median }\end{array}$ & $\begin{array}{c}\text { Covid-19 } \\
\text { negative } \\
\text { patients } \\
\text { (n = 176) } \\
\text { mean/median }\end{array}$ & $\begin{array}{l}\text { Covid-19 positive } \\
\text { patients }(n=9) \\
\text { mean/median }\end{array}$ & p value \\
\hline Male gender & $43(23.2)$ & $40(26.8)$ & $1(11.1)$ & 0,004 \\
\hline Previous $\mathrm{PCl}$ & $26(14.0)$ & $24(13.6)$ & $10(18.9)$ & 0.302 \\
\hline $\begin{array}{c}\text { Previous cardiac } \\
\text { surgery }\end{array}$ & $8(4.3)$ & $7(3,9)$ & $1(11,1)$ & 0,001 \\
\hline COPD & $29(15,6)$ & $27(15.3)$ & $2(22,2)$ & 0.122 \\
\hline NHYA class III/IV & 73 (39.4) & $68(38.6)$ & $4(44.4)$ & 0.453 \\
\hline Hypertension & $125(67,5)$ & $121(68,7)$ & $6(66,6)$ & 0.346 \\
\hline Diabetes & 48 (25.9) & $45(25.6)$ & $4(44,4)$ & 0.023 \\
\hline LVEF \%40-65 & $128(69.1)$ & $122(69.3)$ & $6(66,6)$ & 0.496 \\
\hline LVEF $\% 30-40$ & $57(30,9)$ & $54(30,6)$ & $3(33,3)$ & 0.412 \\
\hline EuroSCORE (median ) & $2.3[1.4-5.2]$ & $2.1[1.5-4.7]$ & $3.9[1.6-6.6]$ & 0.014 \\
\hline Elective & $73(39.4)$ & $72(40,9)$ & $2(22,2)$ & $<0.001$ \\
\hline Urgent & $96(51,9)$ & 89 (50.5) & $6(66,6)$ & \\
\hline Emergency & $16(8,6)$ & $15(8,5)$ & $1(11,1)$ & \\
\hline CABG & $85(45,9)$ & $82(46,5)$ & $3(33.3)$ & 0.004 \\
\hline CABG+valve (any) & $18(9.7)$ & $15(8.5)$ & $2(22,2)$ & \\
\hline Valve only (any) & $48(25,9)$ & $46(26.1)$ & $2(22,2)$ & \\
\hline CPB time (minutes) & $102[75-136]$ & $100[74-135]$ & 114 [87-151] & 0.020 \\
\hline $\begin{array}{l}\text { Aortic cross clamp } \\
\text { time (minutes) }\end{array}$ & 70 [50-97] & 69 [50-97] & 82 [61-115] & 0.024 \\
\hline Ventilation (days) & $2[1-2]$ & $1.5[1-2]$ & $2[1-2.5]$ & 0.666 \\
\hline ICU stay (days) & $2[1-4]$ & $2[1-4]$ & $2[1-3.5]$ & 0.767 \\
\hline Hospital stay (days) & $6[5-10]$ & $7[6-9]$ & $13[7-16]$ & 0.001 \\
\hline Hospital mortality & $9(4,9)$ & $6(3.4)$ & $2(22,2)$ & $<0.0001$ \\
\hline
\end{tabular}

$(\% 11,1) \vee 7(\% 3,9) \mathrm{p}=0.001$ and DM $4(\% 44,4) \vee 45$ (\%25.6) $p=0.023$. Laboratuary values were within normal valuse, including parameteres of infection

\section{Statistical methods}

The analysis was performed using IBM SPSS Statistics for Mac Version 20 (IBM Corp. Released 2011, Armonk, NY). Results are presented as mean (SD) or median [IQR] for continuous variables and groups are compared using Mann-Whitney U test. Categorical data are presented as $\mathrm{n}(\%)$ and compared using chisquared or Fisherís exact tests.

\section{DISCUSSION}

Cardiac surgeons have great responsiblity to ensure the safety of cardiac operations in times of Covid-19. Decision making is more easier in asymptomatic patients with low and medium risk than asymptomatic with high risk. Although routine elective cardiac surgery is stopped, there are many heart patients admitted to the emergency room. It was decided to perform the operations of these patients and the risks related to the surgery were explained to the patient and their relatives. Elective open heart surgeries continued during the time when gradual closure was initiated due to the pandemic. High-risk and symptomatic patients may experience significant cardiac events if they stay at home. There is a conflict in terms of patients and healthcare professionals. Cardiac surgery may expose these patients to a possible COVID-19 infection during hospitalization or 
expose healthcare professionals to patients with a possible infection. However, if these patients are not prepared for surgery, they may have to endure severe consequences related to morbidity and death. Most patients with COVID-19 have mild or no symptoms, and therefore such patients have difficulties to identify ${ }^{(5)}$. The incubation is $4-5$ days after the onset of symptoms, however transmission can occur even in the absence of symptoms ${ }^{(6)}$.

Patients with severe coronary artery disease, left main disease, and triple vessel disease with angina, who are not suitable for conservative or interventional treatment, have high risk of death ${ }^{(7)}$. The same may also apply to patients with symptomatic severe aortic valve stenosis and severe mitral valve insufficiency, ascending aortic aneurysm $>6 \mathrm{~cm}$ in diameter), left-sided endocarditis, large and mobile vegetation. There is two options for these semiemergent patients: to operate immediately by taking risk of infection or to keep them at home by leaving them with the risk of mortality. Since we do not know how long the infectious period will last, we chose the surgery option.

We operated 185 patients who were negative for COVID-19. They had comorbidities such as hypertension and diabetes mellitus. Studies reported an increased risk of developing more severe complications in COVID-19 in patients with high comorbidity ${ }^{(8,9)}$. However, the relationship between COVID-19 and these diseases is still unclear. The novel SARS-CoV-2 virus use the angiotensinconverting enzyme 2 (ACE-2) protein as a cell entry receptor. The ACE-2 protein mostly expressed on the surface of pulmonary, myocardial, and arterial smooth muscle cells. The expression of ACE-2 receptor is increased in patients with comorbid diseases listed above. The increased expression of ACE-2, serve as direct targets of SARS-CoV-2 which may determine the severity of COVID-19 (10,11). Majority of our cohort was male patients. Although, the same prevalence of COVID-19 was found between males and females, male gender has higher mortality ${ }^{H(12)}$. Circulating of high ACE-2 levels in men can be showed as a cause ${ }^{(13)}$.

Postoperative mortality in cardiac surgery is around $4 \%$ and it is well-known fact that mortality risk much greater in urgent and emergent cardiac operations when compared with elective operations ${ }^{(14)}$. The mortality rate is above this value in emergency operations performed during the times of complete closure and in elective operations performed on days when we are gradually closed. Preoperative cardiac function is one of the most important factors that affects the postoperative mortality in cardiac surgery. There is also cardiac risk model such as EuroSCORE II, which helps to predict the postoperative mortality in cardiac surgery ${ }^{(14)}$. In EuroSCORE II, patients are scored by many factors including; demographic, comorbidities, preoperative cardiac status and operation-related. The euroscore values of the patients with covid-positive were high.

Cardiac surgeons and their team should be aware that potentially increasing amounts of aerosol material may occur in procedures that require endotracheal intubation, long-lasting minimally invasive surgery, and redosternotomy, and should be aware of the precautions to be taken (7). Orotracheal intubation can prepare background for infectious contingency, with the sealing of the virus to the invasive ventilation system. Infection can reach the lower respiratory tract and can be spread throughout the body by the cardiopulmonary bypass machine during open heart surgery. In this case, we do not know acute effects of the virus on operating table, but previous experience showed that patients will encounter a clinic ranging from postoperative acute respiratory distress syndrome to the mortality in that setting ${ }^{(15)}$.

Some viral diseases such as hepatitis virus are more frequently observed in patients with certain blood types (16). In a study conducted by Zhao et al (17) they found that the $A B O$ blood type has close relation between COVID-19. Besides, blood management during the operation has aimed to optimise red cell mass, reduce blood loss and enhance anaemia 
tolerance. In addition, these precautions result in reduced blood and blood products transfusion.

Cardiac surgeons should also take the necessary steps for health-workers. Since they work in COVID + environments, health-workers pose a great risk in terms of transmitting the disease to patients. Therefore to minimize the contamination, mobility within the hospital has been reduced. Consulted doctors were visiting the patient under PPE and strict droplet and contact precautions. In addition to the routine surgical consent form, another form which was explaining the possible contamination risks with COVID-19 was also signed to all patients whom underwent surgery.

The daily practice of the cardiac surgery changed sharply. Health Ministry has taken appropriate measures to separate workers / surgeons into groups: a shift system was applied for cardiac surgeons and other health care workers. Staff personnel wore gowns, gloves and face shields or goggles. Surgical masks were also put on the patients. The operating room doors were always closed, and entry and exit were not permitted outside the surgical and anesthesia team. Protective materials moistened or wetted during the operation were replaced immediately. The collected medical waste was performed with the rules set by the Ministry of Health, this collection from hospitals was done after seventy-two hours. Surfaces were cleaned with disinfectants in the operating room and a new patient was taken to the same room 72 hours later. Surgeons' work areas and personal items were cleaned 3 times a day with surface disinfectants. None of the healthcare professionals working in cardiovascular surgery had suspected symptoms of COVID-19, and no one was therefore diagnosed.

A recent large global cohort (7.6\%) of elective and emergency patients with cardiac surgery was diagnosed postoperatively ${ }^{(18)}$. Theoretically, surgery can affect the immune system, accelerating the progression of Covid-19 through the immune response ${ }^{(19)}$, so that patients with incubation of
Covid-19 before surgery may exacerbate the covid processes after surgery ${ }^{(20) .}$

In conclusion, these are challenging times both for cardiac patients and surgeons being pushed to their limits. Elective, urgent and emergent patients should be operated according to the established evidencebased medical concepts while offering a safe environment for health care teams.

Ethics Committee Approval: SBU. Approval was received from Tepecik Training and Research Hospital Clinical Research Ethics Committee (8.6.2020/7-13). Conflict of Interest: The authors declared no conflict of interest.

Funding: No financial support.

Informed Consent: A retrospective study.

\section{REFERENCES}

1. World Health Organization Coronavirus disease 2019 (COVID-19): situation report; Avaible from: https://www. who.int/docs/defaultsource/coronaviruse/ situation-reports/20200330-sitrep-70-covid-19; 2020.

2. Wu F, Zhao S, Yu B, et al. Author Correction: A new coronavirus associated with human respiratory disease in China. Nature 2020;580(7803):E7. PMID: 32296181 [CrossRef]

3. Holshue ML, DeBolt C, Lindquist S, et al; Washington State 2019-nCoV Case Investigation Team. First Case of 2019 Novel Coronavirus in the United States. N Engl J Med 2020;382:929936. PMID: 32004427 [CrossRef]

4. World Health Organization. Rational use of personal protective equipment for coronavirus disease (COVID-19) and considerations during severe shortages. Avaible from: https://www.who.int/publications-detail/rational-use-ofpersonal-protective-equipment-for-coronavirus-disease(covid-19)-and-considerations-during-severeshortages;2020.

5. Han C, Duan C, Zhang S, et al. Digestive Symptoms in COVID19 Patients With Mild Disease Severity: Clinical Presentation, Stool Viral RNA Testing, and Outcomes. Am J Gastroenterol. 2020;115:916-923. PMID: 32301761. [CrossRef]

6. Lauer SA, Grantz KH, Bi Q, et al. The Incubation Period of Coronavirus Disease 2019 (COVID-19) From Publicly Reported Confirmed Cases: Estimation and Application. Ann Intern Med 2020;172:577-582. PMID: 32150748. [CrossRef]

7. Hassan A, Arora RC, Adams C, et al; Cardiac Surgery in Canada During the COVID-19 Pandemic: A Guidance Statement From the Canadian Society of Cardiac Surgeons. Can J Cardiol 2020;36:952-5. PMID: 32299752. [CrossRef]

8. Wang X, Fang X, Cai Z, Wu X, Gao X, Min J, Wang F. Comorbid Chronic Diseases and Acute Organ Injuries Are Strongly Correlated with Disease Severity and Mortality among COVID-19 Patients: A Systemic Review and Meta-Analysis. 
Research (Wash D C) 2020;2020:2402961. PMID: 32377638. [CrossRef]

9. Wang $\mathrm{D}, \mathrm{Hu} \mathrm{B}, \mathrm{Hu} \mathrm{C}$, et al. Clinical Characteristics of 138 Hospitalized Patients With 2019 Novel Coronavirus-Infected Pneumonia in Wuhan, China JAMA 2020;323:1061-9. PMID: 32031570. [CrossRef]

10. Zhou $P$, Yang $X L$, Wang $X G$, et al. A pneumonia outbreak associated with a new coronavirus of probable bat origin. Nature 2020;579:270-273. PMID: 32015507. [CrossRef]

11. Li XC, Zhang J, Zhuo JL. The vasoprotective axes of the reninangiotensin system: Physiological relevance and therapeutic implications in cardiovascular, hypertensive and kidney diseases Pharmacol Res 2017;125:21-38. PMID: 28619367. [CrossRef]

12. Jin JM, Bai P, He W, et al. Gender Differences in Patients With COVID-19: Focus on Severity and Mortality.Front Public Health 2020;8:152. PMID: 32411652. [CrossRef]

13. Patel SK, Velkoska E, Burrell LM. Emerging markers in cardiovascular disease: where does angiotensin-converting enzyme 2 fit in? Clin Exp Pharmacol Physiol 2013;40:551-9. PMID: 23432153. [CrossRef]

14. Nashef SA, Roques F, Sharples LD, Nilsson J, Smith C, Goldstone AR, Lockowandt U. EuroSCORE II. Eur J Cardiothorac Surg 2012;41:734-744. PMID: 22378855. [CrossRef]
15. Groeneveld GH, van Paassen J, van Dissel JT, Arbous MS. Influenza Season and ARDS after Cardiac Surgery. N Engl J Med 2018;378:772-773. PMID: 29466160. [CrossRef]

16. Batool Z, Durrani SH, Tariq S. Association Of Abo And Rh Blood Group Types To Hepatitis B, Hepatitis C, Hiv And Syphilis Infection, A Five Year' Experience In Healthy Blood Donors In A Tertiary Care Hospital. J Ayub Med Coll Abbottabad 2017;29:90-92. PMID: 28712183.

17. Zhao J, Yang $Y$, Huang $H$, et al. Relationship between the $A B O$ Blood Group and the COVID-19 Susceptibility. 2020:2020.03.11.20031096. [CrossRef]

18. COVIDSurg Collaborative. Mortality and pulmonary complications in patients undergoing surgery with perioperative SARS-CoV-2 infection: an international cohort study. Lancet 2020;396:27-38. PMID: 32479829. [CrossRef]

19. Lei S, Jiang F, Su W, et al. Clinical characteristics and outcomes of patients undergoing surgeries during the incubation period of COVID-19 infection. EClinicalMedicine 2020;21:100331. PMID: 32292899. [CrossRef]

20. Sanders J, Akowuah E, Cooper J, et al. Cardiac surgery outcome during the COVID-19 pandemic: a retrospective review of the early experience in nine UK centres. J Cardiothorac Surg. 2021:16:43. PMID: 33752706 [CrossRef] 